\title{
The clinical implications of adult-onset henoch-schonelin purpura
}

\author{
Warit Jithpratuck', Yasmin Elshenawy ${ }^{2}$, Hana Saleh ${ }^{1}$, George Youngberg ${ }^{2}$, David S Chi ${ }^{1}$ and Guha Krishnaswamy ${ }^{1,3^{*}}$
}

\begin{abstract}
Henoch-Schonlein Purpura (HSP) is a small vessel vasculitis mediated by IgA-immune complex deposition. It is characterized by the clinical tetrad of non-thrombocytopenic palpable purpura, abdominal pain, arthritis and renal involvement. Pathologically, it can be considered a form of immune complex-mediated leukocytoclastic vasculitis (LCV) involving the skin and other organs. Though it primarily affects children (over $90 \%$ of cases), the occurrence in adults has been rarely reported. Management often involves the use of immunomodulatory or immune-

suppressive regimens.
\end{abstract}

\section{Introduction}

Henoch-Schonlein Purpura (HSP) is a small vessel vasculitis mediated by IgA-immune complex deposition. It is characterized by the clinical tetrad of non-thrombocytopenic palpable purpura, abdominal pain, arthritis and renal involvement [1]. Pathologically, it can be considered a form of leukocytoclastic vasculitis that can involve not only the skin but other tissues as well. Though it primarily affects children (over $90 \%$ of cases), the occurrence in adults has been rarely reported (3.4 to 14.3 cases per million). This low incidence could be due to either under-diagnosis or misdiagnosis.

Typically the disorder is commoner in males and may follow an infectious illness [2]. In the cases reported in children, the majority (of over $75 \%$ ) of cases presented with an eruption, while up to $66 \%$ presented with abdominal pain and close to $50 \%$ the cases demonstrated renal involvement [2]. In children, the disorder is often selflimiting, while a more complicated course has been described in adults, including a high incidence of renal insufficiency developing in almost $50 \%$ of those patients who showed renal involvement. It appears that patients over 20 years old with bloody stools, relapsing disease and persistent eruption are more likely to progress onto complications [3]. Besides renal disease, cardiac, pulmonary, ocular, gastrointestinal and neurological complications have been described in this disorder. In that sense,

\footnotetext{
* Correspondence: krishnas@mail.etsu.edu

'Departments of Internal Medicine, Quillen College of Medicine, East

Tennessee State University, TN, USA

Full list of author information is available at the end of the article
}

this is truly a multisystem disease and may result in considerable morbidity and mortality in some patients. A variety of disorders have been associated with HSP including infection with Helicobacter pylori, hepatitis B and certain malignancies. The following review describes the course, complications and management of adultonset HSP.

\section{Representative Case Studies \\ Case 1}

A 56 year old man with prior history of hypertension and adult onset diabetes mellitus presented with a skin eruption over the lower extremities of several weeks duration (appearance of the eruption is shown in Figures 1A and 1B). This was accompanied by intermittent, crampy lower abdominal pain and hematuria. The patient denied fever, weight loss, diaphoresis, or arthralgia. He denied a history of a preceding upper respiratory infection. Examination of the patient demonstrated a palpable purpuric eruption over the lower extremities (Figure $1 \mathrm{~A}$ and $1 \mathrm{~B}$ ). Urinalysis revealed proteinuria as well as microscopic hematuria. His serum IgA levels was elevated $(787 \mathrm{mg} / \mathrm{dL}$ with a normal range of $70-400 \mathrm{mg} / \mathrm{dL}$ ), while tests for lupus, vasculitis and hepatitis were negative (Table 1). A skin biopsy showed an inflammatory infiltrate around superficial blood vessels with associated nuclear dust and focal fibrinoid necrosis, consistent with leukocytoclastic vasculitis. This was accompanied by deposition of IgA on vascular walls seen on direct immunofluorescent staining, a pathognomonic feature of HSP.

\section{( Biomed Central}




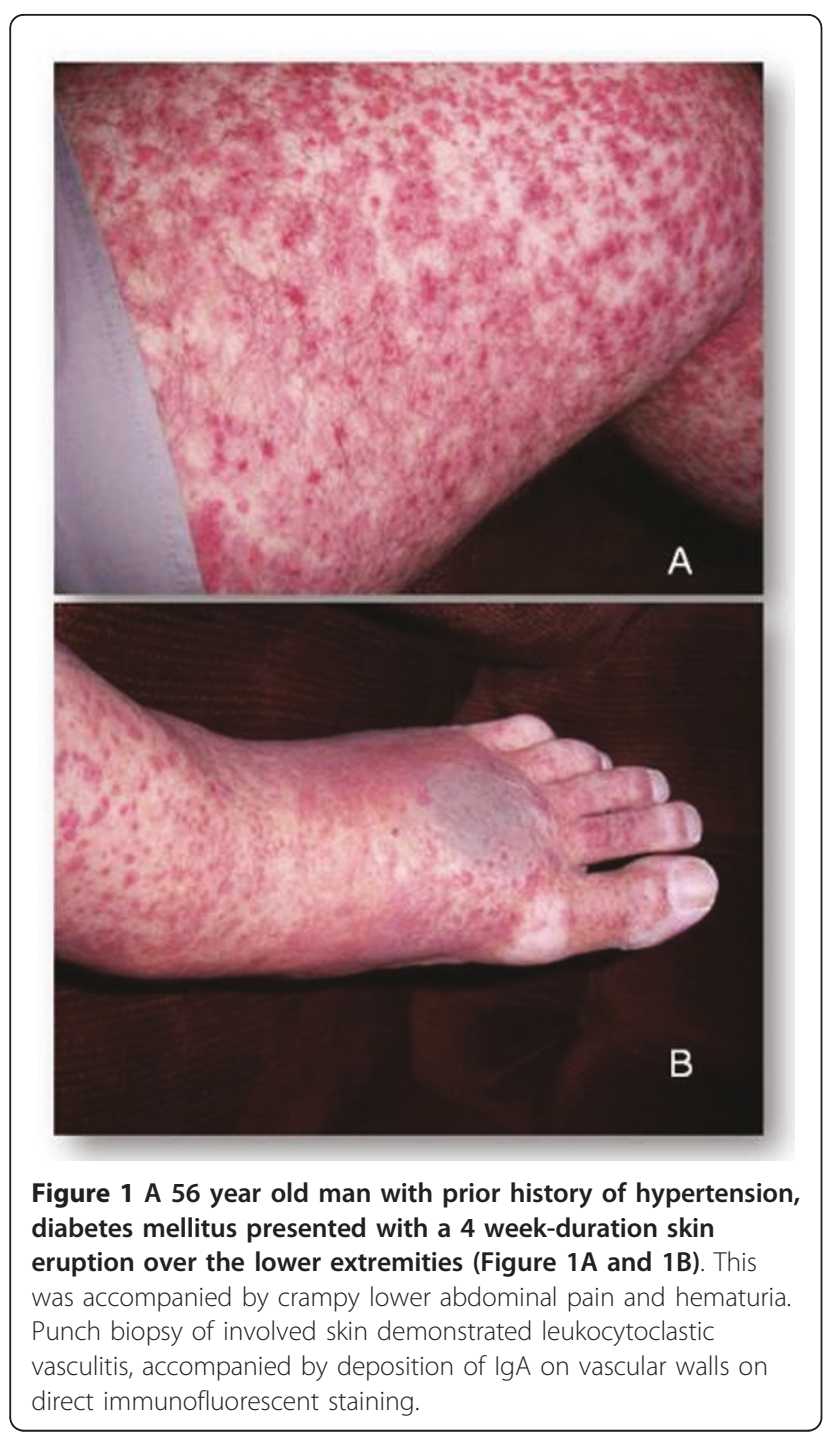

\section{Case 2}

A 57 year old African American man with prior history of cigarette smoking and alcohol abuse, hypertension, coronary artery disease, and hyperlipidemia presented with one week duration of blistering rash on both ankles ascending to his groin area, and involving his hands. This was associated with swelling in both hands and feet without any abdominal pain. He denied any history of antecedent upper respiratory tract infection. Examination revealed edema and a vesiculobullous rash in both hands and feet that showed varied degrees of healing (Figure 2A and 2B). Skin culture growth Stenotrophomonas maltophilia. Urinalysis revealed microscopic hematuria and proteinuria. The spot urine protein-creatinine ratio was 3.7 which confirmed the diagnosis of nephrotic syndrome. Other laboratory results were unremarkable, including hepatitis testing and serologies, with the exception of an elevated CRP level of $220 \mathrm{mg} / \mathrm{dL}$
Table 1 Summary Clinical and Laboratory reviews

\begin{tabular}{|c|c|c|}
\hline Case & Case 1 & Case 2 \\
\hline Age (years) & 56 & 57 \\
\hline Respiratory infection & No & $\mathrm{No}$ \\
\hline Eruption & $\begin{array}{l}\text { Palpable purpuric } \\
\text { rash }\end{array}$ & Blistering rash \\
\hline Abdominal pain & $\begin{array}{c}\text { Crampy abdominal } \\
\text { pain }\end{array}$ & No \\
\hline Arthritis/Arthralgia & No & No \\
\hline Proteinuria g/24 hours & 2.7 & 3.7 \\
\hline Microscopic hematuria & Yes & Yes \\
\hline White cell count & $8.0 \times 10^{3}$ cells $/ \mathrm{mm}^{3}$ & $13.8 \times 10^{3} \mathrm{cells} / \mathrm{mm}^{3}$ \\
\hline Platelet count & $164 \times 10^{3}$ cells $/ \mathrm{mm}^{3}$ & $294 \times 10^{3}$ cells $/ \mathrm{mm}^{3}$ \\
\hline $\mathrm{PT} / \mathrm{INR}$ & Normal & Normal \\
\hline ESR (mm/hour) & 19 & 17 \\
\hline CRP(0-9.9) mg/L & 11.1 & 220 \\
\hline Serum $\lg \mathrm{A} \mathrm{mg} / \mathrm{dL}$ & 787 & 272 \\
\hline $\mathrm{C} 3 / \mathrm{C} 4$ & Normal & Normal \\
\hline Autoantibodies & Negative & Negative \\
\hline $\begin{array}{l}\text { Skin biopsy with } \\
\text { immunofluorescence }\end{array}$ & IgA deposition LCV & IgA deposition LCV \\
\hline $\begin{array}{l}\text { Renal biopsy with } \\
\text { immunofluorescence }\end{array}$ & $\mathrm{N} / \mathrm{A}$ & IgA deposition \\
\hline Treatment & $\begin{array}{l}\text { Colchicine and } \\
\text { Steroid }\end{array}$ & $\begin{array}{l}\text { Colchicine and } \\
\text { Steroid }\end{array}$ \\
\hline
\end{tabular}

$\mathrm{LCV}=$ leukocytoclastic vasculitis.

(normal: 0-9.9 mg/dL: Table 1). Skin biopsy revealed the presence of a perivascular inflammatory infiltrate in the superficial dermal blood vessels, with nuclear dust and focal fibrinoid necrosis, consistent with leukocytoclastic vasculitis(LCV) (Figure 2C), accompanied by the deposition of IgA on vascular walls detected by direct immunofluorescent staining, a pathognomonic feature of HSP. Renal biopsy revealed focal segmental endocapillary proliferation (Figure 2D) with positive immunofluorescent staining for mesangial IgA (Figure 2E).

\section{Pathogenesis}

Henoch-Schonlein Purpura (HSP) is a small vessel vasculitis associated with immunoglobulin $\mathrm{A}(\mathrm{Ig} \mathrm{A})$ complex deposition $[2,4]$. The immune complexes are composed of IgA1 and IgA2 but only IgA1 is found in the inflammatory infiltrate of the disease [5]. Polymorphonuclear leukocytes are recruited by chemotactic factors and cause inflammation and necrosis of vessel walls (focal fibrinoid necrosis) with occasional thrombosis, and with associated red blood cell extravasation, consistent with a form of leukocytoclastic vasculitis [6]. Skin biopsy reveals polymorphonuclear cells or cell fragments around small dermal blood vessels. Immune complexes containing IgA and C3 have been found in skin, intestinal mucosa, joints, and kidneys which are the major 


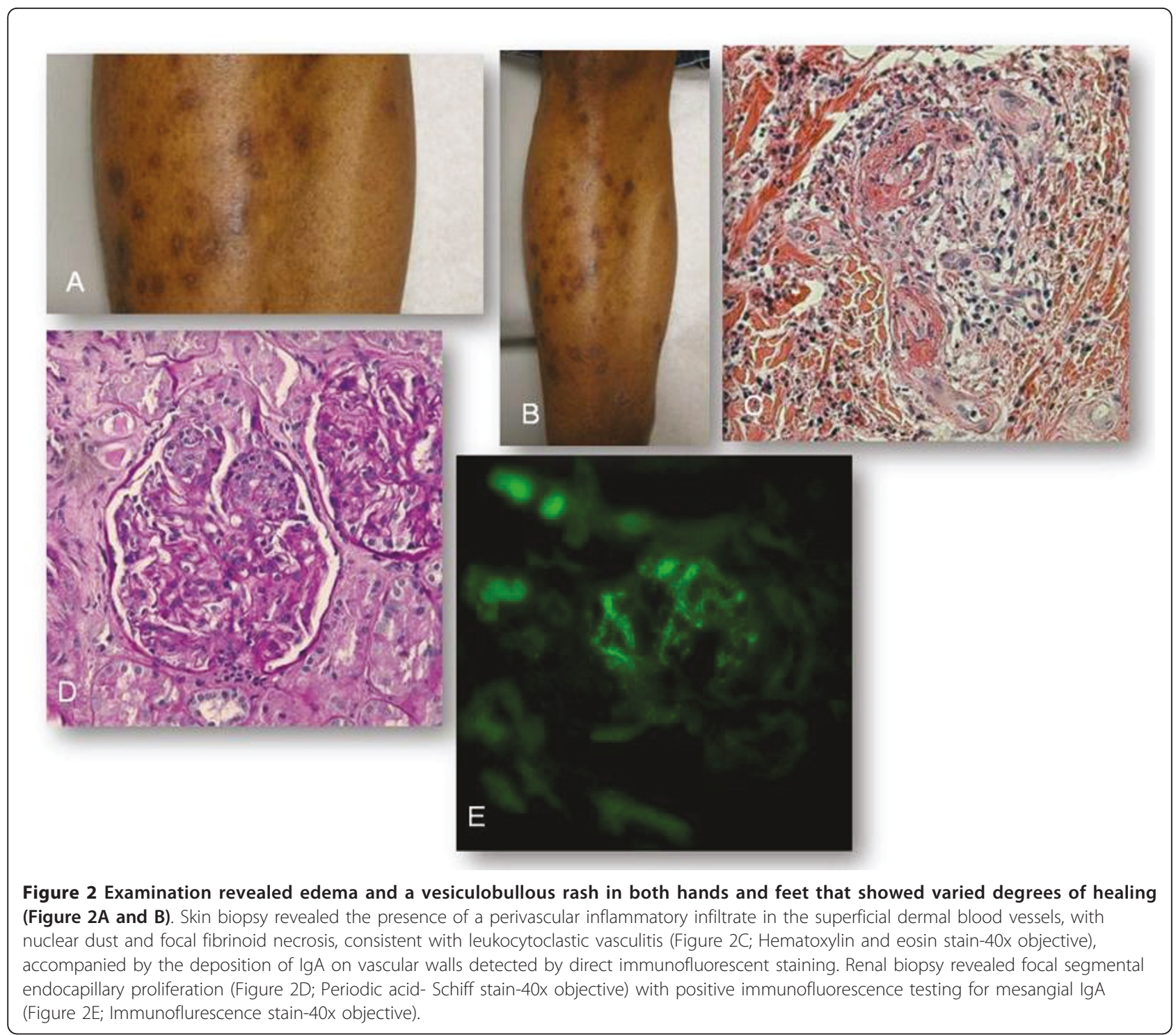

organ sites involved in HSP [6]. In some cases reported in the literature, overlap with polyangiitis or polyarteritisa nodosa-like disease have been reported, resulting in a plethora of severe renal and pulmonary manifestations (Figure 3). Although these cases are anecdotal, their concurrence in a given patient suggests common pathways of immune complex-mediated vasculitis and resultant tissue injury.

\section{Etiology}

The etiology of HSP remains unknown. Various antigenic stimuli have been proposed to trigger this pathology, including a broad spectrum of infectious agents such as infections due to group A Streptococcus, Methicillinresistant Staphylococcus aureus, Helicobactor pylori, Parvovirus B19, Hepatitis B, Human Immunodeficiency Virus, Stenotrophomonas maltophilia (as seen in the second patient reported in this study). Other etiologies proposed including allergens such as drugs, tumor antigens associated with malignancy and certain autoimmune diseases [2,7-11]. Ninety percent of cases occur in children with a favorable outcome as stated earlier, suggesting either unique infectious pathogens common in childhood or other unknown genetic/molecular factors.

\section{Clinical Features}

Adult-onset HSP been described [4,8,12-20], (though $90 \%$ of cases still occur in children), with only 3.4 to 14.3 cases per million reported in the adult population [4]. The diagnostic criteria for HSP are shown in Table 2. We used PubMed to review the English literature for adult-onset HSP cases and the salient aspects of selected cases along with our patients are shown in Table 3. The clinical tetrad of presentations may be in any sequence, 


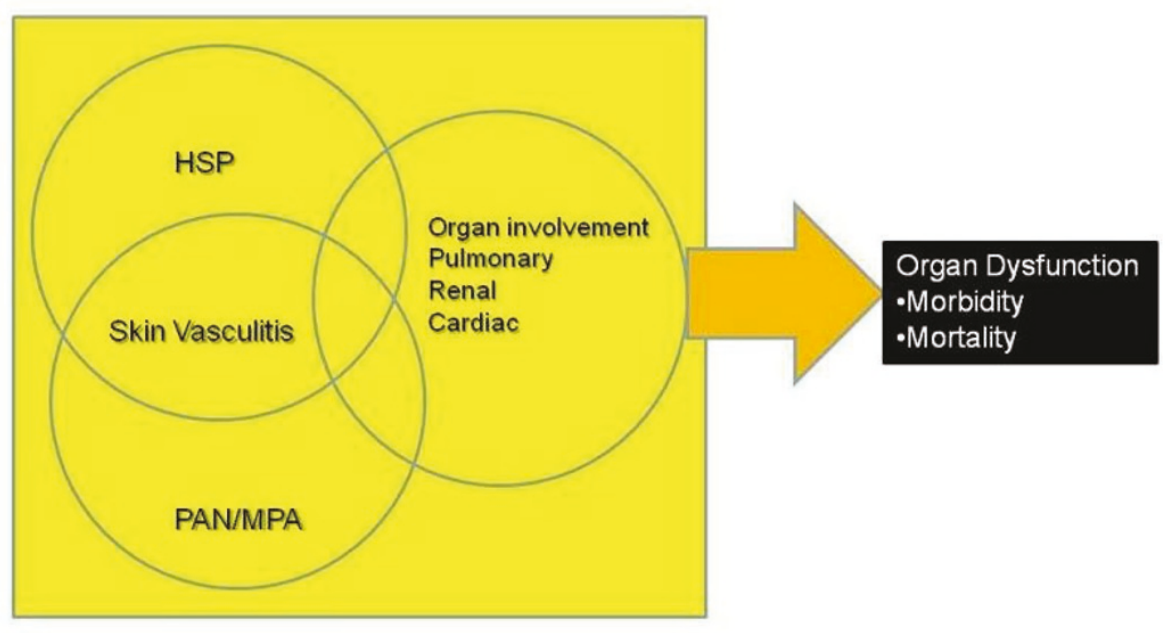

Figure 3 In some HSP cases reported in the literature, overlap with microscopic polyangiitis (MPA) or Polyarteritisa Nodosa (PAN)-like disease have been reported, resulting in a plethora of severe renal and pulmonary manifestations.

with upper respiratory infection prior to the onset of symptoms in about $36.4 \%$ [3]. A retrospective review of 250 adult patients with the disease reported on the following clinical findings [19]: a purpuric rash occurred in $96 \%$, arthritis in $61 \%$, GI disease in $48 \%$ and renal disease in $32 \%$ cases $(99 \%$ of these cases demonstrating proteinuria and $93 \%$ hematuria).

The skin is the most commonly involved site, often starting with an erythematous, macular, or urticarial-type eruption. The lesions then coalesce and evolve into the typical ecchymoses and/or palpable purpura. The lesions tend to appear in crops, with a symmetrical distribution over gravity/pressure-dependent areas such as lower limbs, trunk and upper extremities and frequently accompanied by edema on both extremities. Blistering and hemorrhagic necrotic skin lesions occur in 35\% $[4,19]$.

Table 2 Diagnostic criteria for Henoch-Schonlein Purpura

The European League Against Rheumatism and Paediatric Rheumatology European Society criteria -2006

\begin{tabular}{l} 
Mandatory criterion: Palpable purpura with lower limb \\
predominance \\
Plus at least one of the following criteria: \\
1. Diffuse abdominal pain \\
2. IgA deposition in any biopsy \\
3. Arthritis/arthralgia \\
4. Renal involvement (hematuria and/or proteinuria) \\
\hline
\end{tabular}

American College of Rheumatology criteria-1990

Two or more of the following criteria are needed

1. Age 20 years or less at disease onset

2. Palpable purpura

3. Acute abdominal pain with gastrointestinal bleeding

4. Biopsy showing granulocytes in the walls of small arterioles or venules in superficial layers of skin
Arthritis/arthralgia, the second most common manifestation, occurs in $61 \%$ of cases. It usually transient or migratory, oligoarticular and non-deforming, but often associated with periarticular swelling and tenderness without effusion $[4,19]$

Gastrointestinal involvement is a typical feature of HSP [19,21-23] and occurs in about $48 \%$ of cases. It is caused by submucosal hemorrhage and edema or by vasculitis. The most common presentation is colicky pain or bleeding from an ulcer usually in the second part of duodenum or ileum and/or the rectum. Gastrointestinal symptoms usually develop about one week after the onset of the rash. In about $8 \%$ of cases, it can be the first clinical presentation. In this situation, endoscopy and/or colonoscopy may help establish the diagnosis $[4,19]$. Intussusception may occur in elderly, often presenting as an acute abdominal emergency and may require urgent radiological evaluation for the diagnosis [22]. HSP also has been linked with primary biliary cirrhosis and transient abnormalities of liver function tests. As in our patients, an elevated IgA level occurs in about $60 \%$ and may point to the diagnosis, when the clinician is faced with an unusual lower extremity eruption in the setting of abdominal pain.

Renal impairment, the most serious complication, ranges from microscopic hematuria to a full blown nephrotic syndrome [19]. It is detected in $45-85 \%$, with a risk of progression to renal insufficiency in $30 \%$ of adult-onset HSP. It is usually detected within two months of the eruption, but sometimes may manifest as late as six months after initial onset of the disease [3]. The most frequent pathology observed is a mesangial or endocapillary proliferative glomerulonephritis [19]. Some studies have suggested that certain genetic 
Table 3 Selected reports of HSP in adult patients

\begin{tabular}{|c|c|c|c|c|c|}
\hline $\begin{array}{l}\text { Patient } \\
\text { (report) }\end{array}$ & $\begin{array}{l}\text { Age/ } \\
\text { gender }\end{array}$ & Clinical/Labs & Histological diagnosis & Treatment & Outcome \\
\hline 1 & $24 / \mathrm{M}$ & $\begin{array}{l}\text { Purpuric rash, arthritis, abdominal pain, Hematuria } \\
\text { and proteinuria }\end{array}$ & $\begin{array}{l}\text { Skin: LCV with IgA deposition } \\
\text { Mesangial IgA deposition }\end{array}$ & $\begin{array}{l}\text { Glucocorticoids } \\
\text { Cyclophosphamide }\end{array}$ & Remission \\
\hline 2 & $68 / M$ & $\begin{array}{l}\text { Abdominal pain with diarrhea, purpuric rash, } \\
\text { elevated sedimentation rate }\end{array}$ & Skin: LCV with IgA deposition & None & $\begin{array}{l}\text { Spontaneous } \\
\text { remission }\end{array}$ \\
\hline 3 & $77 / M$ & $\begin{array}{l}\text { Abdominal pain with diarrhea purpuric rash, } \\
\text { hematuria, elevated IgA level and sedimentation } \\
\text { rate }\end{array}$ & Skin: LCV with IgA deposition & $\begin{array}{l}\text { Glucocorticoids } \\
\text { Cyclophosphamide }\end{array}$ & Remission \\
\hline 4 & $69 / M$ & Pustular rash, abdominal pain myocardial infarction & $\begin{array}{l}\text { Endocapillary proliferative nephritis } \\
\text { with IgA deposition subendocardial } \\
\text { LCV }\end{array}$ & Glucocorticoids & Deceased \\
\hline 5 & $\begin{array}{l}20 / \\
M, 76 / F \\
67 / F\end{array}$ & $\begin{array}{l}\text { Purpuric rash, arthralgia, hematuria hemoptysis, } \\
\text { hypoxia, bilateral infiltrate }\end{array}$ & $\begin{array}{l}\text { Skin: LCV with IgA deposition } \\
\text { pulmonary interstitial fibrosis }\end{array}$ & Glucocorticoids & Remission \\
\hline 6 & $20 / F$ & $\begin{array}{l}\text { Purpuric rash, arthralgia, hematuria, proteinuria, } \\
\text { seizure }\end{array}$ & $\begin{array}{l}\text { Skin:LCV EEG: Transient focal } \\
\text { abnormality MRI: normal }\end{array}$ & $\begin{array}{l}\text { Glucocorticoids } \\
\text { Dilantin }\end{array}$ & Remission \\
\hline $7^{*}$ & $56 / M$ & $\begin{array}{l}\text { Purpuric rash, crampy abdominal pain Hematuria, } \\
\text { proteinuria, elevated IgA level }\end{array}$ & Skin: LCV & Colchicine & Remission \\
\hline $8^{*}$ & $57 / M$ & Blistering rash, hematuria, Nephrotic syndrome & $\begin{array}{l}\text { Skin: LCV Endocapillary proliferative } \\
\text { nephritis mesangial IgA deposition }\end{array}$ & $\begin{array}{l}\text { Glucocorticoids } \\
\text { Colchicine }\end{array}$ & $\begin{array}{l}\text { Partial } \\
\text { remission }\end{array}$ \\
\hline
\end{tabular}

LCV: Leukocytoclastic vasculitis; $\mathrm{M}=$ Male; $\mathrm{F}=$ Female.

* Cases described in this report.

polymorphorphisms, such as those involving cytokine genes (IL1 receptor antagonist, IL8 or IL1 beta) have been associated with increased risk of renal involvement [24-26]. Age of onset, the presence of renal impairment and hematuria at the onset, abdominal pain as an initial presentation, persistent eruption, renal pathology with fibrinoid necrosis and the number of sclerotic glomeruli are significant predictors of renal disease $[3,19,27]$.

\section{Other Complications}

Unusual presentations include pulmonary involvement [28-30], scrotal pain [31], central, peripheral nervous system involvement and seizure [32-34] as well as cardiac involvement [35-37]. Pulmonary involvement can manifest as diffuse alveolar hemorrhage and occasionally as usual interstitial pneumonia or interstitial fibrosis. There is an association between HSP and malignancy $[7,9,38]$, most commonly associated with solid tumors. An evaluation for occult malignancy may therefore reasonable in adults (especially those above 40 years of age) diagnosed with HSP.

\section{Diagnosis}

There are two criteria proposed by American College of Rheumatology [39] and the new criteria by European League Against Rheumatism (EuLAR) and Pediatric Rheumatology Society (PReS) [40] as listed in Table 2. The diagnosis is usually based on clinical presentation with tissue biopsy demonstrating leukocytoclastic vasculitis associated with IgA deposition (by immunofluorescence). Skin biopsy should be obtained from the lesion less than 24 hours old and typically shows the classical leukocytoclastic vasculitis in postcapillary venule with IgA deposition. Renal biopsy should be performed in case of uncertain diagnosis or severe renal impairment such as nephrotic syndrome. Endoscopy and/or colonoscopy play a major role in helping diagnosis of the patients with the gastrointestinal involvement as their initial presentation.

No specific test is diagnostic for HSP. Elevated serum IgA levels have been associated with HSP in about $60 \%$ of cases [19]. Urine analysis can vary from microscopic hematuria to nephritic-syndrome range proteinuria. Coagulation studies and the platelet count are usually normal. Inflammatory markers such as sedimentation rate (ESR) and $C$ reactive protein (CRP) levels are often elevated. Serum level of insulin like growth factor (IGF) and IGF binding protein 3 have been proposed as a marker for determination of renal involvement as well as the terminal complement complex (SC5b-9) level as a surrogate for disease activity in HSP [41]. These need independent confirmation.

\section{Treatment}

Most cases of LCV are self-limited and may require little or no intervention. In mild cases a nonsteroidal anti-inflammatory agent may suffice. Colchicine is the treatment of choice when the skin lesions are severe [42]. Colchicine inhibits polymorphonuclear leukocyte chemotaxis by inhibiting spindle formation, blocking lysosome formation and stabilizing the lysosome membranes. The suppressive effect of colchicine on the inflammatory 
Table 4 A summary of treatment options for Henoch-Schonlein Purpura

\begin{tabular}{ll}
\hline Medication & Indication \\
\hline Acetaminophen, NSAID & Mild eruption, arthritis \\
\hline Colchicine & Severe or recurrent skin disease \\
\hline Oral glucocorticoids & $\begin{array}{l}\text { Severe eruption, cutaneous edema, } \\
\text { severe colicky abdominal pain, } \\
\text { scrotal and testicular involvement }\end{array}$ \\
\hline Parenteral glucocorticoids & $\begin{array}{l}\text { Same as oral; unable to tolerate } \\
\text { oral medications }\end{array}$ \\
\hline High dose parenteral pulse & Nephrotic range proteinuria \\
glucocorticoid & $\begin{array}{l}\text { Rapidly progressive } \\
\text { High dose IV pulse glucocorticoids } \\
\text { combined with other forms of } \\
\text { immunosuppression (such as }\end{array}$ \\
cyclophosphamide) & $\begin{array}{l}\text { Hemorrhagic involvement of lungs } \\
\text { or brain }\end{array}$ \\
\hline Plasmapheresis and/or IGIV & $\begin{array}{l}\text { Refractory to combination therapy } \\
\text { Massive hemorrhage in }\end{array}$ \\
& gastrointestinal or other organs \\
\hline
\end{tabular}

IV = intravenous; IGIV = intravenous immunoglobulin.

pathway may explain its efficacy on the skin lesions. The sulfone, Dapsone, has also been used to treat the vasculitic component of HSP; it has antioxidant scavenger effects and may suppress the generation of toxic free radicals in neutrophils. It also inhibits the synthesis of IgG and IgA antibodies and prostaglandin $\mathrm{D}_{2}$ [43]. Glucocorticoids (such as prednisone at a dosage of 1-2 mg/ $\mathrm{kg}$ daily) have been used to treat gastrointestinal symptoms successfully [44].

Aggressive therapy with corticosteroids or cyclophosphamide has not been shown to be beneficial in reversing the renal disease except among patients with the crescentic form of nephritis. Plasmapheresis and immunoglobulin have been used in refractory combination therapy. These treatment options are summarized in Table 4 [43,45-49].

\section{Conclusion}

HSP is a heterogeneous disorder manifesting in adults with palpable purpura/skin vasculitis, hematuria and proteinuria, often with preserved renal function. The diagnosis can be easily missed: A high degree of suspicion and requesting immuno-fluorescence studies in suspected cases are mandatory to establishing the diagnosis. Skin biopsy and immunofluorescence confirm the presence of LCV with IgA deposition which is the pathognomonic finding in HSP. Colchicine is a treatment of choice for severe or recurrent LCV. Adults with HSP carry a different prognosis, and the development of hematuria may be a harbinger for more serious complications such as nephritic or nephrotic syndrome. Malignancy is common in adult onset HSP and work up should be done to exclude this possibility.

\section{Author details}

${ }^{1}$ Departments of Internal Medicine, Quillen College of Medicine, East Tennessee State University, TN, USA. ${ }^{2}$ Department of Pathology, Quillen College of Medicine, East Tennessee State University, TN, USA. ${ }^{3}$ The James $H$. Quillen VA Medical Center, Johnson City, TN, USA.

\section{Authors' contributions}

WJ carried out the literature review, case report description, and clinical presentations

YM carried out the pathology sections and prepared for pathology slides and legends

HS participated in clinical presentation

GY participated in pathology sections advisors

DC assisted in review

GK provided the material and patient data, organized the manuscript, edited figures, assisted in discussion, generated references and participated in the editing and final approval of the manuscript

All authors read and approved the final manuscripts.

\section{Competing interests}

The authors declare that they have no competing interests.

Received: 4 January 2011 Accepted: 27 May 2011

Published: 27 May 2011

\section{References}

1. Sohagia $A B$, et al: Henoch-schonlein purpura-a case report and review of the literature. Gastroenterol Res Pract 2010, 2010:597648.

2. Reamy BV, Williams PM, Lindsay TJ: Henoch-Schonlein purpura. Am Fam Physician 2009, 80:697-704.

3. Hung SP, et al: Clinical manifestations and outcomes of HenochSchonlein purpura: comparison between adults and children. Pediatr Neonatol 2009, 50:162-168.

4. Lopez Meiller MJ, et al: Henoch-Schonlein Purpura in adults. Clinics (SaO Paulo) 2008, 63:273-276.

5. Saulsbury FT, et al: Henoch-Schonlein purpura in children. Report of 100 patients and review of the literature. Medicine (Baltimore) 1999, 78:395-409.

6. Helander SD, De Castro FR, Gibson LE: Henoch-Schonlein purpura: clinicopathologic correlation of cutaneous vascular IgA deposits and the relationship to leukocytoclastic vasculitis. Acta Derm Venereol 1995, 75:125-129.

7. Hong YH: Renal cell carcinoma presenting as Henoch-Schonlein purpura with leukocytoclastic vasculitis, hematuria, proteinuria and abdominal pain. Rheumatol Int 2010, 30:1373-1376.

8. Hoshino C: Adult onset Schonlein-Henoch purpura associated with Helicobacter pylori infection. Intern Med 2009, 48:847-851.

9. Mitsui $H$, et al: A clinical study of Henoch-Schonlein Purpura associated with malignancy. J Eur Acad Dermatol Venereol 2009, 23:394-401.

10. Sugimoto $T$, et al: Henoch-Schonlein purpura in a patient with human immunodeficiency virus infection. Rheumatol Int 2008, 28:615-616.

11. Shin Jl, Lee JS: Hepatitis B virus infection and Henoch-Schonlein purpura. J Dermatol 2007, 34:156.

12. Kunicka A, Pruszczyk P, Kryst A: Henoch-Schonlein purpura: an atypical cause of abdominal pain in a 70-year-old man: case report. Pol Arch Med Wewn 2009, 119:509-513.

13. Goel SS, Langford CA: A 72-year-old man with a purpuric rash. Cleve Clin J Med 2009, 76:353-360.

14. Diehl MP, Harrington T, Olenginski T: Elderly-onset Henoch-Schonlein purpura: a case series and review of the literature. J Am Geriatr Soc 2008, 56:2157-2159.

15. Maripuri S, Fervenza FC: 71-year-old man with shortness of breath and rash. Mayo Clin Proc 2008, 83:1388-1391.

16. Grivceva-Panovska V, Grivceva SK, Serafimoski V: Henoch-Schonlein purpura in an adult patient: extragastric, cutaneous manifestation of helicobacter pylori infection. Prilozi 2008, 29:291-301.

17. Knoll BM, Valles A, Hogan MC: 56-Year-old man with rash, abdominal pain, and arthralgias. Mayo Clin Proc 2007, 82:745-748.

18. Kellerman PS: Henoch-Schonlein purpura in adults. Am J Kidney Dis 2006, 48:1009-1016. 
19. Pillebout $\mathrm{E}$, et al: Henoch-Schonlein Purpura in adults: outcome and prognostic factors. J Am Soc Nephrol 2002, 13:1271-1278.

20. Patrignelli R, Sheikh SH, Shaw-Stiffel TA: Henoch-Schonlein purpura. A multisystem disease also seen in adults. Postgrad Med 1995, 97:123-124.

21. Gatselis NK, et al: Primary biliary cirrhosis and Henoch-Schonlein purpura: report of two cases and review of the literature. Liver Int 2007, 27:280-283.

22. Goda F, et al: Colo-colic intussusception associated with HenochSchonlein purpura in adults. J Gastroenterol Hepatol 2007, 22:449-452.

23. Zhang $Y$, Huang $X$ : Gastrointestinal involvement in Henoch-Schonlein purpura. Scand I Gastroenterol 2008, 43:1038-1043.

24. Amoli MM, et al: Interleukin 1 receptor antagonist gene polymorphism is associated with severe renal involvement and renal sequelae in HenochSchonlein purpura. J Rheumatol 2002, 29:1404-1407.

25. Amoli MM, et al: Interleukin 8 gene polymorphism is associated with increased risk of nephritis in cutaneous vasculitis. J Rheumatol 2002, 29:2367-2370.

26. Amoli MM, et al: Interleukin 1 beta gene polymorphism association with severe renal manifestations and renal sequelae in Henoch-Schonlein purpura. J Rheumatol 2004, 31:295-298.

27. Garcia-Porrua C, et al: Predictive factors for renal sequelae in adults with Henoch-Schonlein purpura. J Rheumatol 2001, 28:1019-1024.

28. Usui $K$, et al: Diffuse pulmonary hemorrhage as a fatal complication of Schonlein-Henoch purpura. J Dermatol 2007, 34:705-708.

29. Soloukides A, et al: Pulmonary involvement in Henoch-Schonlein purpura. Emerg Med J 2006, 23:886.

30. Nadrous HF, et al: Pulmonary involvement in Henoch-Schonlein purpura. Mayo Clin Proc 2004, 79:1151-1157.

31. Mizuashi $M$, et al: Facial purpura and scrotal swelling: a quiz. HenochSchonlein purpura. Acta Derm Venereol 2009, 89:549-550

32. Garzoni $L$, et al: Nervous system dysfunction in Henoch-Schonlein syndrome: systematic review of the literature. Rheumatology (Oxford) 2009, 48:1524-1529.

33. Ohnuma K, et al: An adult case of Henoch-Schonlein purpura complicating common peroneal nerve mononeuropathy. Mod Rheumatol 2009, 19:73-79.

34. Fielding RE, et al: Seizures complicating adult Henoch-Schonlein purpura. Nephrol Dial Transplant 1998, 13:761-762.

35. Lutz HH, et al: Henoch-Schonlein purpura complicated by cardiac involvement: case report and review of the literature. Am J Kidney Dis 2009, 54:e9-15.

36. Shin $\mathrm{Jl}$, et al: Cardiac manifestations of Henoch-Schoenlein purpura: IgA mediated vasculitis or Rheumatic fever? Eur J Pediatr 2007, 166:627.

37. Polizzotto MN, et al: Cardiac involvement in Henoch-Schonlein purpura. Intern Med J 2006, 36:328-331.

38. Zurada JM, Ward KM, Grossman ME: Henoch-Schonlein purpura associated with malignancy in adults. J Am Acad Dermatol 2006, 55:565-S70.

39. Mills JA, et al: The American College of Rheumatology 1990 criteria for the classification of Henoch-Schonlein purpura. Arthritis Rheum 1990, 33:1114-1121.

40. Ozen $\mathrm{S}$, et al: EULAR/PReS endorsed consensus criteria for the classification of childhood vasculitides. Ann Rheum Dis 2006, 65:936-941.

41. Kawana S, Nishiyama S: Serum SC5b-9 (terminal complement complex) level, a sensitive indicator of disease activity in patients with HenochSchonlein purpura 68. Dermatology 1992, 184:171-176.

42. Pyne $D$, Mootoo R, Bhanji A: Colchicine for the treatment of recurrent Henoch-Schonlein purpura in an adult. Rheumatology (Oxford) 2001, 40:1430-1431.

43. Sarma PS: Dapsone in Henoch-Schonlein purpura. Postgrad Med J 1994, 70:464-465.

44. Sharma A, et al: Successful treatment of severe gastrointestinal involvement in adult-onset Henoch-Schonlein purpura. Singapore Med J 2007, 48:1047-1050.

45. Pillebout $E$, et al: Addition of cyclophosphamide to steroids provides no benefit compared with steroids alone in treating adult patients with severe Henoch Schonlein Purpura. Kidney Int 2010, 78:495-502.

46. Rech J, et al: Plasmapheresis therapy in an elderly patient with rapidly progressive Henoch-Schonlein purpura with disseminated organ involvement. Clin Rheumatol 2007, 26:112-114.
47. Schmaldienst $S$, et al: Severe nephrotic syndrome in a patient with Schonlein-Henoch purpura: complete remission after cyclosporin A. Nephrol Dial Transplant 1997, 12:790-792.

48. Kusuda A, et al: Successful treatment of adult-onset Henoch-Schonlein purpura nephritis with high-dose immunoglobulins. Intern Med 1999, 38:376-379.

49. Bayrakci US, et al: Effect of early corticosteroid therapy on development of Henoch-Schonlein nephritis. J Nephrol 2007, 20:406-409.

doi:10.1186/1476-7961-9-9

Cite this article as: Jithpratuck et al:: The clinical implications of adultonset henoch-schonelin purpura. Clinical and Molecular Allergy 2011 9:9.

\section{Submit your next manuscript to BioMed Central and take full advantage of:}

- Convenient online submission

- Thorough peer review

- No space constraints or color figure charges

- Immediate publication on acceptance

- Inclusion in PubMed, CAS, Scopus and Google Scholar

- Research which is freely available for redistribution

Submit your manuscript at www.biomedcentral.com/submit
C Biomed Central 